\title{
SPACE MONITORING OF ANTHROPOGENIC IMPACTS ON SOILS AND THE WATER ENVIRONMENT ASSOCIATED WITH SOLID DOMESTIC WASTE: SCIENTIFIC AND EDUCATIONAL ASPECTS (SPACE ENVIRONMENTAL WATCH)
}

\begin{abstract}
Shakhramanyan M. A., L. Kazaryan M. L., Richter A. A.
Abstract. A new technology of monitoring and control of solid waste, based on the reception and processing of the Earth remote sensing data with different spatial resolution and spectral resolution is proposed. The technology is based on the processing of multispectral and hyperspectral images from space in special software products, the identification and analysis of solid waste from small (suburban, road clutter) to large (industrial and urban landfills), depending on the spatial and spectral resolution of the space image. At present, software complexes for processing (deciphering) of space images of solid domestic waste and their adjacent territories have been developed.

With the help of these software complexes, it became possible to identify unauthorized landfills, to determine the correctness of operation of existing landfills in accordance with existing regulatory documents, to determine the sequence of liquidation of various landfills, depending on the degree of their negative impact on the environment and human health.

The introduction of the proposed technology can provide substantial assistance to various ministries, departments and the public in detecting at an early stage the places of clutter, the so-called pre-landfills, which, if not to take preventive measures, can become real garbage dumps with all the ensuing environmental problems.

It is important that schools and universities, for which this work will be attractive both in terms of planning and implementation of research activities, education of young people with an active life position in terms of ecology and environmental protection, be included in the implementation of the "Space Ecological Watch" project.

It should be borne in mind that SHW landfills are basically "the reactors" in which various physical-chemical reactions (combustion, oxidation, etc.) are rapidly occurring; besides SWLs are of considerable interest for educational and research processes both in secondary and higher schools. Moreover, many parameters of these physical-chemical reactions in the time-mode, close to the real one, can be controlled by methods of remote sensing of the Earth from space.

We propose to organize the International Competition "Space Environmental Watch" with the participation of students and schoolchildren from different countries of the world. This Competition will be based on the technology described above, will have the following nominations: - identification of unauthorized landfills; - landfills Information validity check; - assessment of the impact of solid waste landfills on the environment. According to the results of the competition, a digital map with identified unauthorized garbage dumps and an assessment of their impact on the environment can be made on the Internet.
\end{abstract}

Kew words: landfill object, SHW landfill, garbage dump, metasubject, MatLab, educational process, training modules, teaching activities

\section{INTRODUCTION}

Nowadays the problem of the influence of the solid domestic waste on the environment is one of the most acute one.

Today's world is full of the so-called global problems ("rich-poor", global climate change, terrorism, etc.). But one more particular problem becomes more and more relevant with the time. This is the problem of wastes and environmental pollution, determined by the low level of "garbage morality" in almost all countries of the world.

The area of littering increases from year to year. Littering leads to different forms of soil degradation, pollution of water and air; it causes the death of animals and wilting of vegetation; increases the possibility of chronic diseases of residents in the vicinity of large debris. [1-10]

A big "contribution" to the volume of trash is made by the countries of Asia. A huge amount of waste enters the ocean. Now in the world ocean there are real "garbage islands" occupying vast areas.

A large Pacific garbage spot was formed by dragging currents of debris through the water into a whirlpool. According to scientific studies by Charles Moore, the spot has a size of 700 thousand to 15 million sq $\mathrm{km}$ or more (from $0.41 \%$ to $8.1 \%$ of the total area of the Pacific Ocean). Probably there is more than one hundred million tons of garbage on this site. We should assume the existence of garbage spots in other oceans, formed by oceanic circular rotation and by the sea currents. 
The victims of littering of soil and water are, first of all, representatives of the fauna. Some get entangled in the garbage, which becomes their captivity and grave. Others simply deform and grow together with the waste. Others confuse it with food and die (Fig. 1).

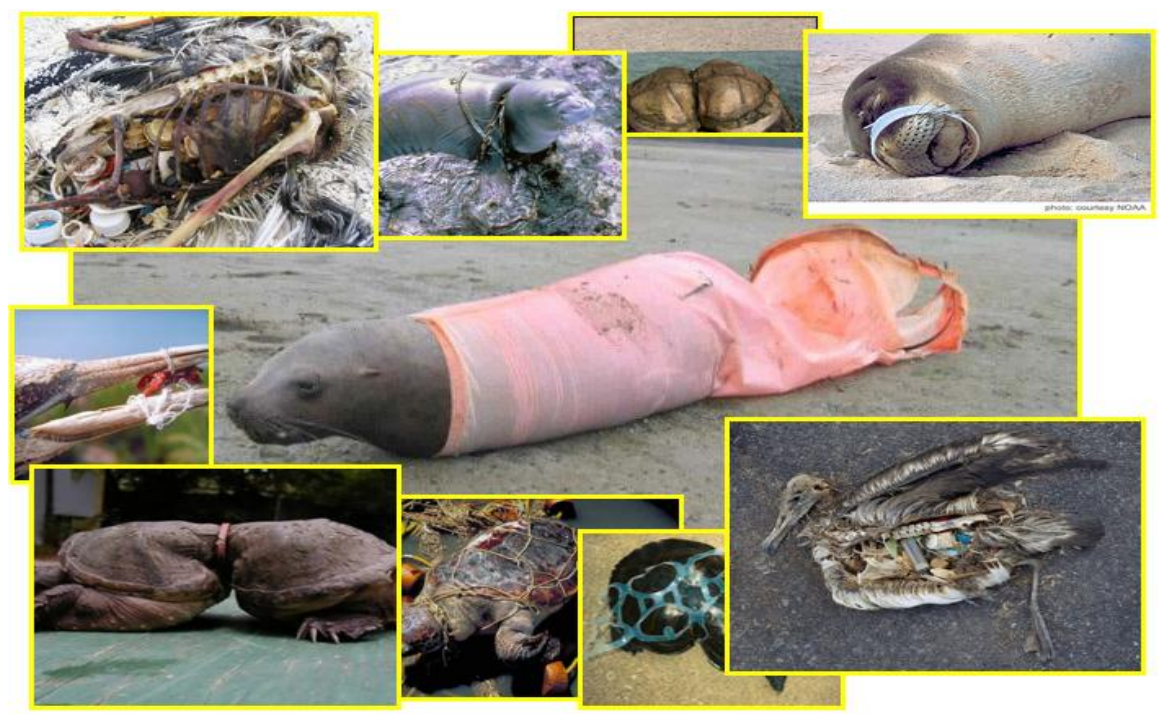

Fig. 1. Victims of the garbage disaster influence (pictures from Internet)

\section{SPACE MONITORING OF THE SOLID HOUSEHOLD WASTE (SHW) LANDFILL SITES}

The technology of space monitoring of landfills poses three major tasks [11-16]:

- detection of unauthorized objects of waste disposal (OWD);

- control design, operation and reclamation of known OWD - solid household waste (SHW) and industrial waste (IW) landfills, municipal landfills, waste disposal sites, etc.);

- assessment of the state of the natural environment exposed to the OWD.

Images of the earth's surface, which form the basis of remote sensing, are obtained by shooting with satellite equipment of various surface areas when a planet orbits a planet and transmits the digitized signal to the receiving and transmitting antenna. Then the signal is subjected to primary and secondary processing. [2]

The scheme of the OWD space monitoring includes blocks (subsystems):

1. Development of databases;

2. Detection of unauthorized OWDs;

3. Control of design, operation and reclamation of authorized OWD;

4. Estimation of the parameters of the OWD and the influence of the OWD on the natural environment;

5. Sub-satellite monitoring (using external data).
One of the methods for detecting OWD by cosmic images is by the exact coincidence of a combination of the values of the spectral brightness coefficients (SBC) over the entire image with reference combinations. The reference object occupies a known area on the image, and these reference combinations of SBC values are known for it. [3]

In the given example (Fig. 2), the standard (blue area) is a landfill of SHW landfill site and IW Savvino, the city of Zheleznodorozhny in the Moscow region. It identified 48 objects, of which 44 - OWD, and 4 - false objects. A fragment of the observation area with the designation of identified objects (red areas) and examples of OWDs discovered is shown. The initial data is a photograph of Landsat 5 TM. [3]

One way to isolate OWD components from space images is from the dependencies of the SBC reports the coverage areas of the component on different channels from each other, to which the multiple regression line of the component (all channels from some base channel) corresponds. Each pixel in the image is checked for a distance to these lines for each component. The pixel belongs to that component, the distance to which is minimal. [4]

In this example (Fig. 3) a fragment of the surface of the SHW landfill Kuchino (settlement Saltykovka, Balashikha district, Moscow region), is divided into 6 components. The general component image and 6 particular component images are shown. 
Satellite images

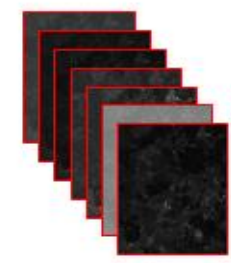

Number of false objects -4 The total number of detected objects - 48

Probability of the detection error $-\mathrm{P}=4 / 48=8 \%$
Fragment of the observation

The examples of found objects region

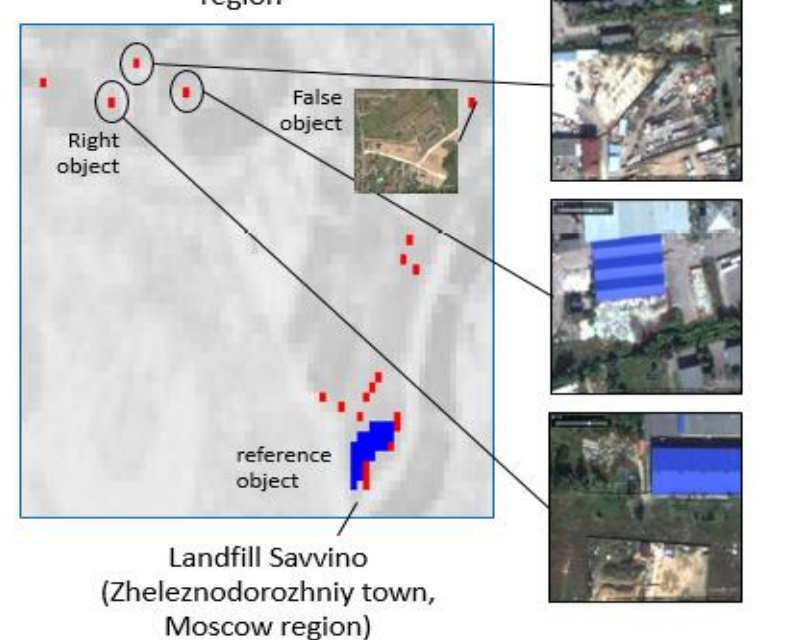

Fig. 2. Example of the SHW landfill automatic detection

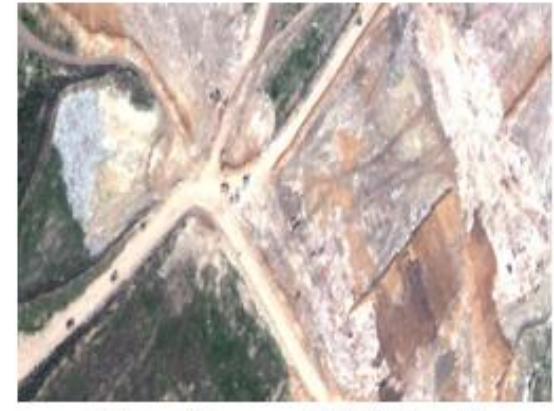

Original image (WorldView2)

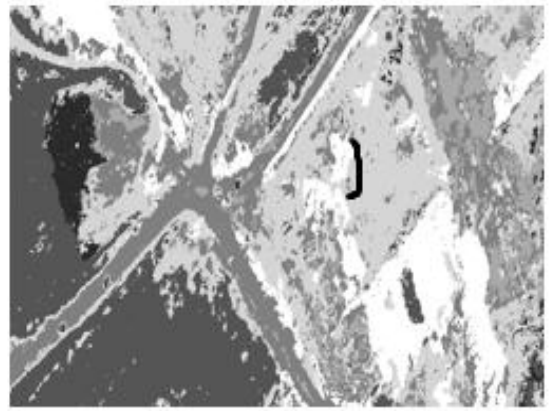

Surface classes

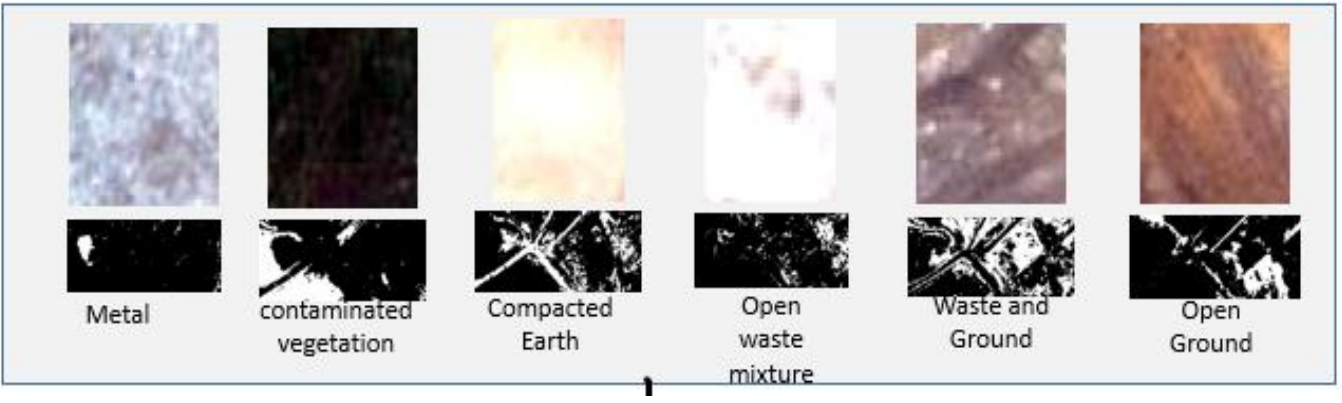

Fig. 3. Example of allocation of landfill components - Landfill Kuchino (Balashiha district, Moscow region)

Using the methods of space monitoring, it is possible to evaluate the numerous parameters of the OWD and their effect on the natural environment. Fig. 4 shows an example of a change in the state of the soil in the vicinity of the Kuchino landfill. The growth of soil degradation in the vicinity of the Kuchino landfill is seen from remote sensing data from outer space over a long period of time (over 25 years, from 1987 to 2011). Yellow indicates an average level, in red - a high (steady) level of soil degradation. 1 - SHW landfill Kuchino, Balashikhinsky district, Moscow region; 2 - the village of Fenino. Yellow area - average level of soil degradation; Red area - high level of soil degradation. [17-23]

\section{ASSESSMENT OF THE DESIGN, EXPLOITATION AND REMEDIATION REQUIREMENTS}

Table 1 lists the requirements for the design, operation and recultivation (DOR) of solid waste landfills, which can be estimated from space monitoring data. 


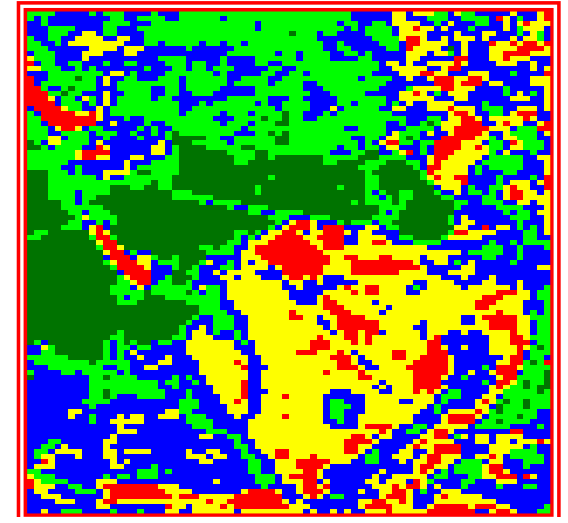

(a)

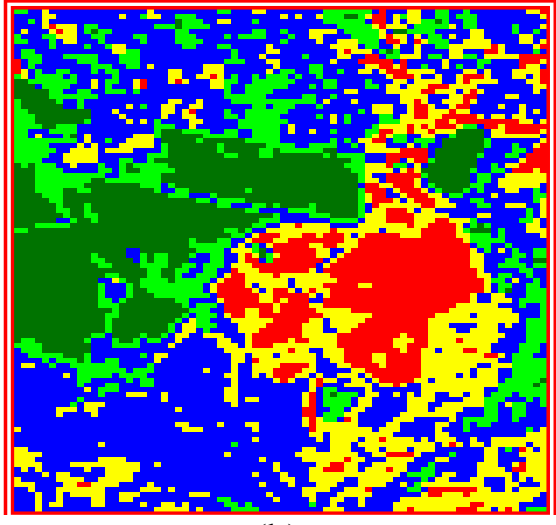

(b)

Fig. 4. Growth of soil degradation in the vicinity of the SHW landfill Kuchino according to the Earth remote sensing from space: a) 11 April 1987; б) 11 June 2011

Table 1. Requirements for RED of landfills of solid household waste and OP

\begin{tabular}{|l|l|}
\hline № & \multicolumn{1}{c|}{ Requirement } \\
\hline \multicolumn{1}{|c|}{ Design Requirements } \\
\hline 1 & Availability and layout of the main facilities of the landfill \\
\hline 2 & Relation of terrain and polygon filling scheme \\
\hline 3 & Presence of a drainage ditch, design of planting trees \\
\hline 4 & Design of foundation ditches of polygons \\
\hline 5 & Design of the base shields \\
\hline 6 & Monitoring of the sanitary protection zone \\
\hline 7 & Distance to the nearest town-planning objects \\
\hline & \\
\hline 1 & Organization of warehousing (area, volume, order, speed of filling) \\
\hline 2 & Availability of household, construction, industrial waste, volumes \\
\hline 3 & Wetting of waste in fire hazardous periods \\
\hline 4 & The order of work (development, backfilling, consolidation) \\
\hline 5 & Presence and composition of intermediate screens (surfaces and slopes) \\
\hline 6 & The presence of cluttering neighborhoods \\
\hline 7 & Backfill with vegetative soil, gardening \\
\hline 8 & Quality of waste insulation from the environment \\
\hline 9 & Availability of hazardous waste \\
\hline 10 & Stage of degradation, humification, assessment of the composition of the landfill \\
\hline 11 & Coating with final protective screens (surfaces, slopes) \\
\hline & \\
\hline 1 & Availability of storage of waste \\
\hline 2 & Backfill with vegetative soil, gardening \\
\hline 3 & Planting trees and shrubs on the slopes \\
\hline 4 & Coverage of technological and biological remediation screens \\
\hline 5 & Quality of technical reclamation \\
\hline 6 & Quality of biological reclamation \\
\hline 7 & The quality of work (agricultural, forestry and construction) for the further use of land \\
\hline & \\
\hline
\end{tabular}


Fig. 5 shows the fulfillment of some requirements: "The availability and layout of the main facilities of the landfill, the layout of the object among the objects of the natural environment" (a); "Monitoring of the sanitary protection zone" (b); "Distance to the nearest townplanning objects" (c). In the figure (a): 1 - storage area, 2 - cluttering of the vicinity by the radioactive waste (RW), 3 - soil development, 4 - fields, 5 - offices, premises, 6 ejection of the filtrate, 7 - riv . Pechorka, 8 - Fenino Cemetery, 9 - the village of Fenino, 10 - the pond. In the figure (b): 1 - storage area, 2 - sanitary protective zone. In the figure (in): 1, 2, 3, 6, 19, 20, 21 -water bodies, 4, 22 - industrial zone, 5 - boiler room, parking lot, etc., 7 , 17,18 - the forest, 8, 13, 15, 16 - fields, 9 - territory of a driving school, 10 - neighborhood of the village Pavlino, 11, 12 -village Fenino, 14 - cemetery. The arrow indicates the distance from the edge of the polygon to the village. Fenino $(30 \mathrm{~m})$, the point - the village. Fenino (adjacent dwelling house).

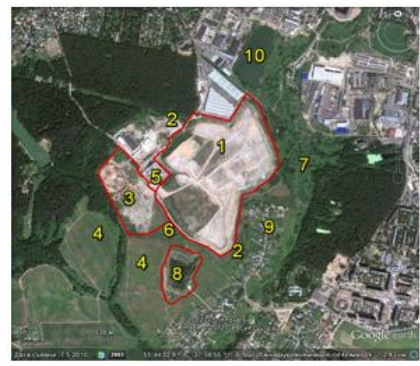

(a)

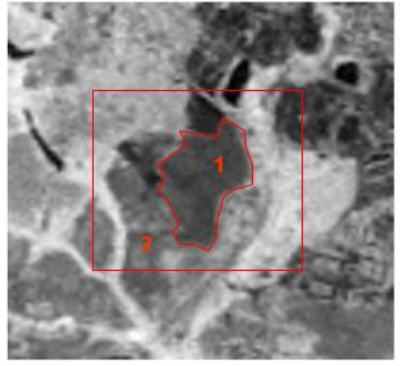

(b)

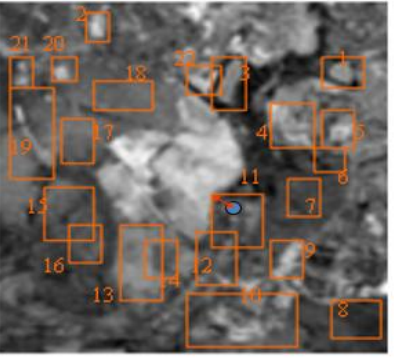

(c)

Fig. 5. Verification of the fulfillment of some design requirements for large OWD landfill (landfill of Kuchino)

\section{THE RESULTS OF THE STUDENTS AND SCHOOLCHILDREN PROJECT WORK IN SPACE MONITORING OF LANDFILLS}

Successful experience in applying OWD landfill space monitoring results in the educational and design research activities of schoolchildren and students makes it possible to draw a conclusion about the advisability of introducing into the programs of additional education in schools and the program of master's training in universities, sections related to methods and technologies of space monitoring of solid domestic and industrial waste disposal sites, and their impact on the natural environment.

Fig. 6 shows the variants of design work for schoolchildren in 2013-2014: "Investigation of the geometric parameters of polygons and littered territories" (a); "Investigation of the temperature regime and types of chemical reactions" (b); "Isolation of components of the surface of a polygon and a neighborhood" (c). [1]

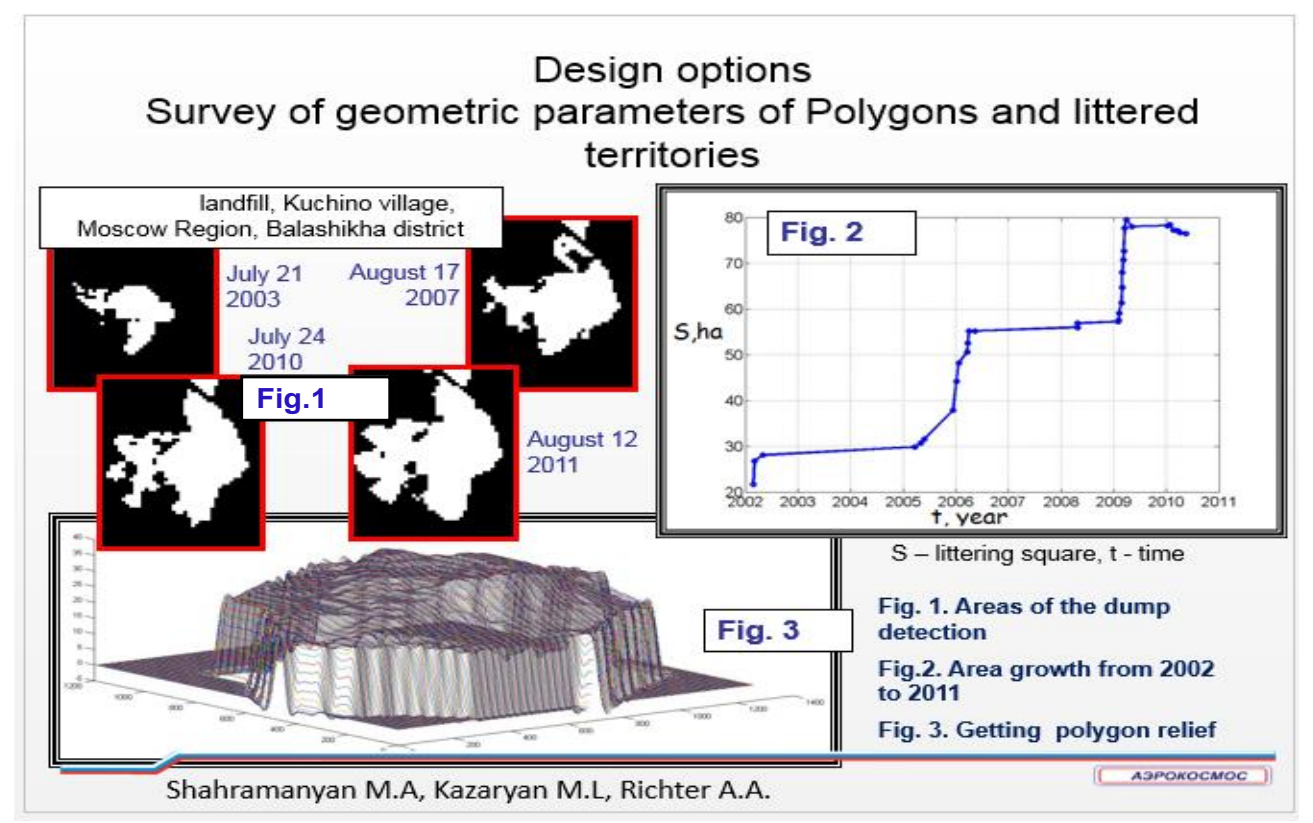

(a) 


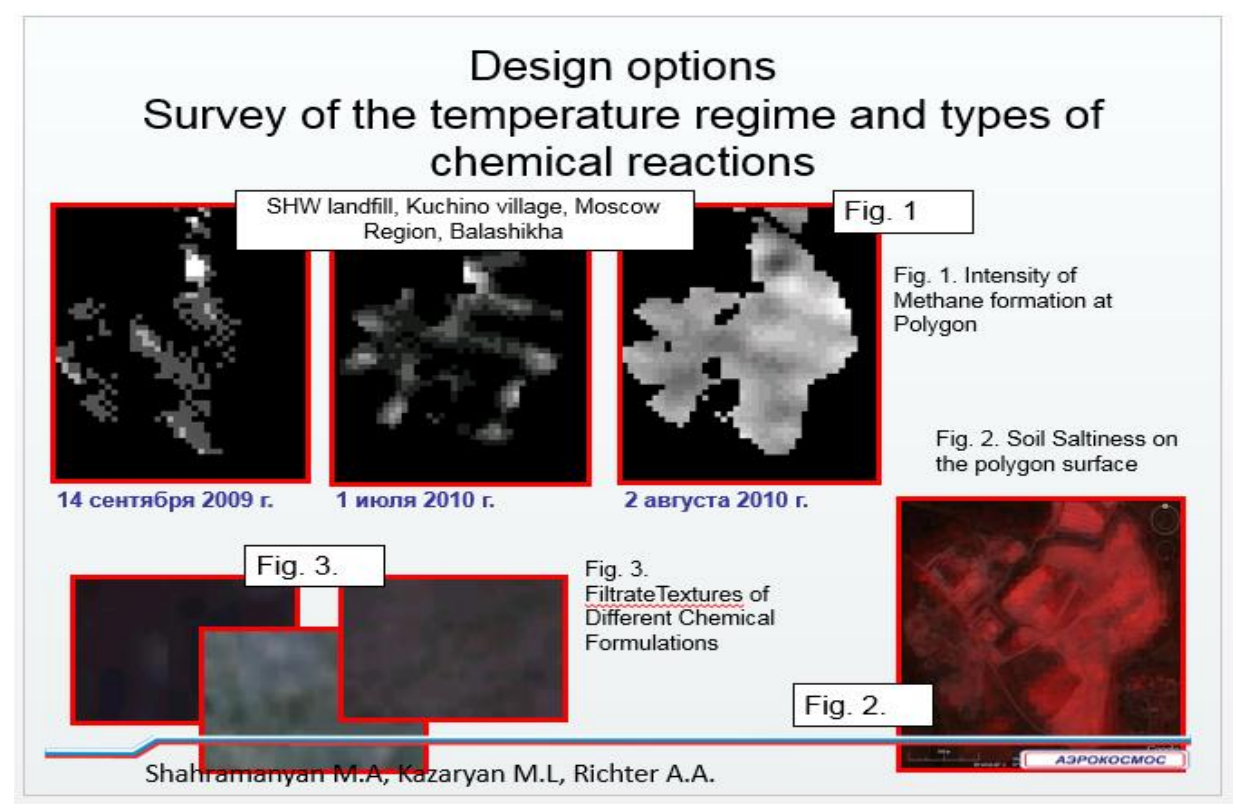

(b)

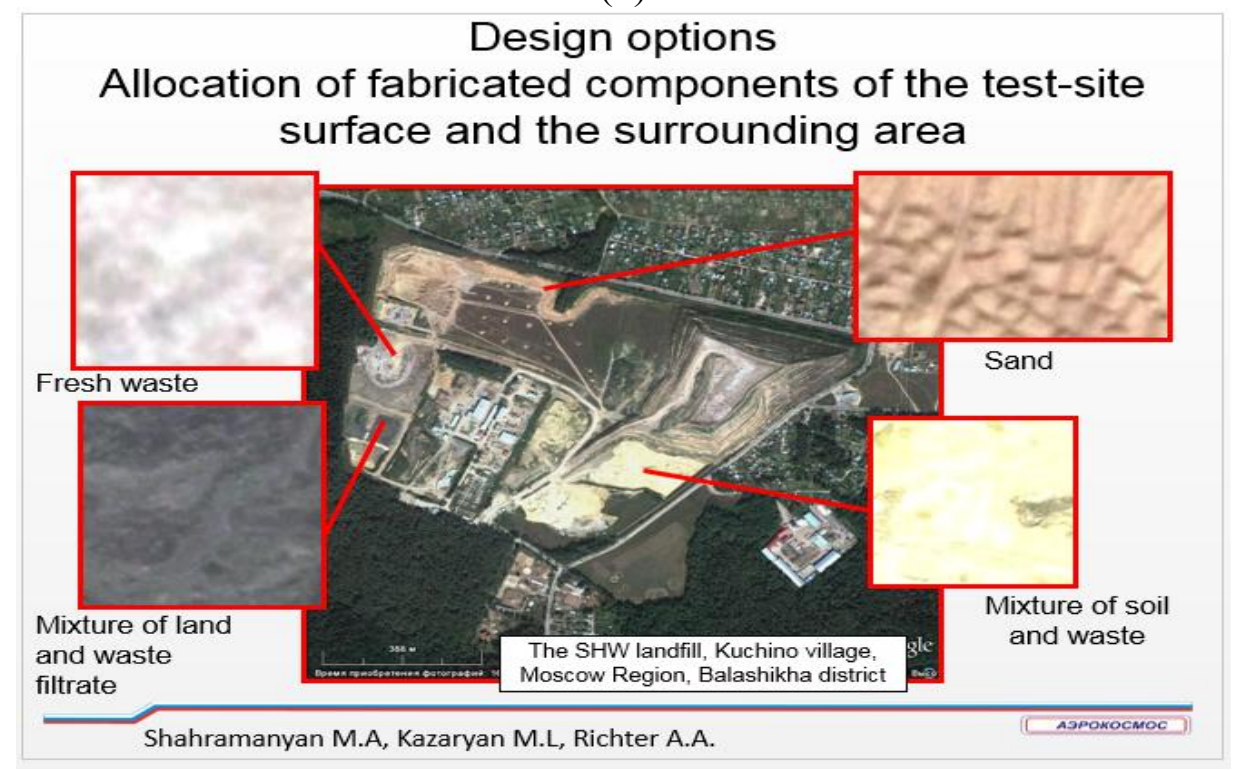

(c)

Fig. 6. Examples of design work for schoolchildren

\section{RESULTS}

1. The problem of the environment littering is an acute ecological problem of modernity;

2. Substantial assistance in solving of this problem can be provided by methods and technologies of the Earth remote sensing of from space;

3. To solve the problem of the natural environment monitoring it is advisable to involve young students and schoolchildren.

\section{Problem Solution:}

To organize and hold an international contest: "Space environmental watch", students and schoolchildren from around the world participating.

Nominations:

- Identification of unauthorized landfills;

- Monitoring the correct operation of existing solid waste landfills;

- Assessment of the impact of solid domestic waste on the natural environment.

According to the results of this competition " $\mathbf{A}$ global digital map" with identified unauthorized landfills and the assessment of their influence on the environment can be placed on the Internet. 


\section{REFERENCES}

1. Richter A.A., Shahramanyan M.A., Kazaryan M.L, Murynin, M.A. Estimation of Geometric Parameters of Littering Regions from Multispectral Space Images // Fundamental research. - 2015, No. 2 (13). - P. 2866-2870.

2. Richter A.A., Shahramanyan M.A., Kazaryan M.L, Murynin, M.A. Development of a method for assessing the degree of soil degradation based on long-term observations // Fundamental research. 2015, No. 2 (14). - P. 3095-3099

3. Kazaryan M.L, Shahramanyan M.A., Richter A.A. Method of Automation of Detection and Separation of Waste Disposal Objects // Fundamental research. - 2015, No. 8 (2). - P. 281-286

4. Shahramanyan, M.A., Richter A.A. Methods and technologies of space monitoring of waste disposal facilities in the interests of ensuring the ecological safety of territories: Teachers book - M .: Publishing Center of the Russian State University of Oil and Gas after I.M. Gubkin, 2013. - 241 p.

5. Rebekah Shultz Colby, Game-based Pedagogy in the Writing Classroom/Original Research Article/Computers and Composition, Volume 43, March 2017, Pages 55-72

6. Lauren Marshall Bowen, The Limits of Hacking Composition Pedagogy/Original Research Article/Computers and Composition, Volume 43, March 2017, Pages 1-14

7. Max Grossman, Maha Aziz, Heng Chi, Anant Tibrewal, Shams Imam, Vivek Sarkar, Pedagogy and tools for teaching parallel computing at the sophomore undergraduate level/Original Research Article/Journal of Parallel and Distributed Computing, In Press, Corrected Proof, Available online 9 January 2017

8. Destiny R. Brady, Marilyn E. Asselin, Exploring outcomes and evaluation in narrative pedagogy: An integrative review/Review Article/Nurse Education Today, Volume 45, October 2016, Pages 1-8

9. Ecological monitoring / Karakeyan VI, Sevryukova EA / Textbook / Moscow, 2016. Ser. 58 Bachelor. Academic course (1st ed.)

10. Garcieva EI, Shirochenkova MN, Youth environmental movement: the experience of Moscow region, In the collection: The world of science and innovation works of the II International Scientific and Practical Conference. 2016. P. 98-102

11. Fatneva E.A., Geoecological monitoring of the state of the urban environment, Innovative technologies in science and education. 2016. No. 4 (8), p. 27-33

12. Voronich S.S., Roeva N.N., Zaitsev D.A., Pakhomov D.E., Khlopaev A.G., Shadskaya Yu.S., Grebenkin N.N., Baranov A.N., Methodology and principles of organization of environmental monitoring system of the environment (by the example of the city of Moscow), Ecological systems and devices. 2016. № 4, p. 3-13.

13. Tulupova O.V., Kozlova T.V., Ivashchenko S.A., Dyutakov A.M., Suchkova I.A., Derzhurina E.N., Metaprojective lesson in modern school education, Nizhny Novgorod Education,. 2010, № 2, p. 105-114

14. Boyarkina Yu..A, Metaprojective approach as a basis for the development of the information educational space in conditions of implementing the second generation standards, Regional Education of the XXI century: problems and prospects. 2011. № 1, p. 49

15. Shahramanyan M.A., Kazaryan M.L., Nartikoyeva A.O., Abaeva I.N. Space monitoring of the state of the environment for the development of the system of additional environmental education // Modern problems of science and education. 2015. № 3, p. 392

16. Ashihmina, T.Ya. Environmental Monitoring: Textbook. Allowance / T.Ya. Ashikhmina, G.Ya. Kantor, A.N. Vasilyeva, V.M. Timonyuk, L.V. Kondakova, A.S. Sityaov, VI Kolchanov, N.D. Ohorzin, V.A. Kopysov, T.S. Noskova, G.A. Voronina, V.P. Isupov, N.M. Alykina, V.M. Syutkin, N.V. Zhdanov, E.A. Shtina; Ed. T.Ya. Ashihminoy. - Moscow: 2005. - 416 p.

17. 12Xianhua Li, Zuyi (Jacky) Huang,An inverted classroom approach to educate MATLAB in chemical process control/Original Research Article/Education for Chemical Engineers, Volume 19, April 2017, p. 1-12

18. Huan Qin, Zijian Liu, Yu Liu, Haolong Zhong, An object-oriented MATLAB toolbox for automotive body conceptual design using distributed parallel optimization /Original Research Article/ Advances in Engineering Software, Volume 106, April 2017, p. 19-32

19. Chapman, Stephen J. MATLAB Programming for Engineers/ Stephen J Chapman. USA, 2007. - 567 p.

20. Gekeler, Eckart W. Mathematical Methods for Mechanics: A Handbook with MATLAB Experiments/Eckart W Gekeler. USA, 2008. - 624p.

21. Schowengertt, R.A. Remote sensing. Models and methods of image processing: a tutorial R.A. Schowengertt; transl. from Eng. A.V. Kiryushina, A.I. Demyanikova. - Moscow: Technosphere, 2013. - 624 p.

22. Shahramanyan M.A., Kazaryan M.A., Richter A.A. Identification of fissure lesions from space images of low spatial resolution Landsat // Information and space. - 2016, No. 3. - P. 91-96.

23. A. Richter, M. Kazaryan, M. Shakhramanyan, R. Nedkov, D. Borisova, N. Stankova, I. Ivanova, M. Zaharinova Estimation of thermal characteristics of waste disposal sites using lendsat satellite images// Comptes rendus de l'Academie bulgare des Sciences. - 2017, №. 2, V. 70, - p. 253-261 


\title{
КОСМИЧЕСКИ МОНИТОРИНГ НА АНТРОПОГЕННИТЕ ВЬЗДЕЙСТВИЯ ВЪРХУ ПОЧВАТА И ВОДНАТА СРЕДА СВЬРЗАНИ С ТВЬРДИТЕ БИТОВИ ОТПАДЫЦИ: НАУЧНИ И ОБРАЗОВАТЕЛНИ АСПЕКТИ (КОСМИЧЕСКО НАБЛЮДЕНИЕ НА ОКОЛНАТА СРЕДА)
}

\author{
Шакраманян М. А., Казарян М. Л., Рихтер А. А.
}

Резюме: Предложена е нова технология за мониторинг и контрол на твърдите отпадъци, базирана на приемането и обработката на данните от дистанционното наблюдение на Земята с различна пространствена и спектрална разделителна способност. Технологията се основава на обработката на мултиспектрални и хиперспектрални изображения от космоса в специални софтуерни продукти, идентифицирането и анализа на твърди отпадъци от малки (крайградски, пътни) до големи (промишлени и градски) депа, в зависимост от пространствената и спектралната разделителна способност на изображението. В момента са разработени софтуерни комплекси за обработка (дешифриране) на пространствени изображения на. твърди битови отпадъци и прилежащите им територии.

С помощта на тези софтуерни комплекси стана възможно да се идентифицират нелегални сметища, да се определи правилността на експлоатацията на съществуващите депа в съответствие със съществуващите нормативни документи, да се определи последователността на ликвидацията на различните депа, в зависимост от степента на тяхното отрицателно въздействие върху околната среда и човешкото здраве.

Въвеждането на предложената технология може да предостави значителна помощ на различни министерства, отдели и обществеността, за да открият на ранен етап местата на затрупване, т. нар. предварително депонирани отпадъци, които, ако не се вземат превантивни мерки, могат да станат истински сметища с всички последващи екологични проблеми.

Важно е училищата и университетите, за които тази работа ще бъде атрактивна както по отношение на планирането и осъществяването на научноизследователски дейности, така и на образованието на младите хора с активна житейска позиция по отношение на екологията и опазването на околната среда, да бъдат включени в изпълнението на Проект " Космическо наблюдение на околната среда ".

Трябва да се има предвид, че депата за твърди битови отпадъци са основно "реакторите", в които бързо се появяват различни физико-химични реакции (изгаряне, окисляване и т.н.); освен това твърдите битови отпадъци, представляват значителен интерес за образователните и изследователските процеси в средното и висшето училище. Нещо повече, много параметри на тези физико-химични реакции във времевия режим, близки до реалния, могат да бъдат контролирани чрез методи за дистанционно наблюдение на Земята от космоса.

Ние предлагаме да организираме международен конкурс "Космическо наблюдение на околната среда" с участието на студенти и ученици от различни страни по света. Този конкурс ще се основава на технологията, описана по-горе и ще има следните номинации: идентификация на нелегални депа; проверка на валидността на информацията; оценка на въздействието на депата за твърди отпадъци върху околната среда. Според резултатите от конкурса може да се направи цифрова карта в Интернет с идентифицирани нелегални сметища за боклук и оценка на въздействието им върху околната среда.

Ключови думи: депо, твърди битови отпадъци, сметище, мета субект, MatLab, образ:ователен процес, модули за обучение, учебни дейности

Prof. Mihail Shakhramanyan

Researching Institute "Aerocosmos"

Gorohovskiy line, 4, 105064, Moscow, Russia

Assoc.Prof. Maretta Kazaryan

Financial University at

Government of Russian Federation

Vladikavkaz branch,

Molodeghnaya str.7, 362001 Vladikavkaz, Russia

Assist.Prof. Andrey Richter

Researching Institute "Aerocosmos"

Gorohovskiy line, 4, 105064, Moscow, Russia 